I.I. Кузьмич, кандидат юридичних наук, полковник

НУОУ імені Івана Черняховського

\title{
УПРАВЛІННЯ ДИСТАНЦІЙНИМ НАВЧАННЯМ У ВИЩИХ ВІЙСЬКОВИХ НАВЧАЛЬНИХ ЗАКЛАДАХ В УМОВАХ СЬОГОДЕННЯ
}

У статті розглядається актуальність та умови впровадження дистанційного навчання у вищих військових навчальних закладах України як основної форми підготовки військових фахівиів в умовах сьогодення.

Ключові слова: дистанційне навчання; Збройні Сили Украӥни; система військової освіти.

Постановка проблеми. Події на Сході України змінили погляди керівництва Збройних Сил України, українського суспільства та фахівців у галузі управління військовою освітою на якість, зміст і шляхи підготовки військових фахівців у вищих військових навчальних закладах (BВН3). Нові виклики, які поставленні перед Збройними Силами України, змушують шукати новітні форми і технології навчальної діяльності, які спрямовані на ефективну підготовку військових фахівців та їх адаптацію до міжнародних стандартів освіти. Для вирішення цих задач потрібне використання у навчальному процесі інформаційних технологій, зокрема дистанційного навчання, які підвищать ефективність процесу навчальної діяльності та дозволять йому набути рис, притаманних процесу підготовки військових фахівців у державах-членах НАТО. Водночас упровадження дистанційної форми навчання у ВВНЗ відбувається дуже повільно, адже військова освіта $є$ вельми консервативною галуззю, для якої характерні підходи в підготовці фахівців ще радянських часів. Змінити стан справ може, в першу чергу, запровадження управлінських технологій, які врахують стан військової освіти сьогодні та цільові орієнтири їі модернізації у найближчі роки. Саме одним 3 цих орієнтирів і є запровадження у ВВНЗ дистанційної освіти до 2020 року згідно вимог Стратегічного оборонного бюлетеня України.

Отже, перед науковцями постає проблема відсутності управлінських технологій в галузі військової освіти, здатних забезпечити високу якість підготовки військовослужбовців засобами дистанційного навчання. Її розв' язання вимагає, зокрема, об'єктивної оцінки стану системи управління дистанційним навчанням у ВВНЗ та визначення напрямів модернізації цієї системи.

Аналіз останніх досліджень та публікацій. Стратегія національної безпеки України яка була затверджена Указом Президента України у 2015 році [1], де йдеться, у тому числі, й про “запровадження інтегрованої системи освіти, бойової і спеціальної підготовки персоналу для органів сектору безпеки і оборони із залученням викладачів, інструкторів із держав - членів НАТО, СС, формування нової культури безпеки" ставить завдання удосконалення системи військової освіти та підготовки кадрів та впровадження дистанційного навчання у ВВНЗ.

Проте не створена системи єдиного освітнього простору на основі 
дистанційного навчання в військових навчальних закладах, яка сприятиме розвитку інформаційно-освітньої мережі для підготовки військових фахівців для Збройних Сил України.

Мета та завдання дослідження. Метою дослідження є визначення стану управління дистанційним навчанням у ВВНЗ та перспектив його модернізації. Задля реалізації цієї мети необхідно схарактеризувати зовнішні обставини та нормативні вимоги, що вимагають широкого застосування технологій дистанційного навчання у військовій освіті, переваги дистанційної форми навчання перед іншими в контексті підготовки військовослужбовців, визначення недоліків системи управління дистанційним навчанням у ВВНЗ та перспектив іiї удосконалення.

Виклад основного матеріалу. Аналіз сучасної воєнно-політичної обстановки довкола України вказує на те, що вона стає більш напруженою. Це пов’язано з агресією Російської Федерації проти України, тимчасовою окупацією Автономної Республіки Крим, проведенням антитерористичної операції на Сході України, нарощуванням військових угруповань біля кордонів України та іншими факторами.

Бойові дії на Сході України надали реальну оцінку якості підготовки військових фахівців, їх спроможності виконувати завдання щодо керування військовими частинами та підрозділами у бойових умовах.

При цьому виявлено недоліки, причиною яких у багатьох випадках був низький рівень підготовки військовослужбовців у навчальних закладах та системі професійної підготовки.

Серед основних вмінь, якими має володіти сучасний військовий керівник слід виокремити такі:

гнучко адаптуватися до змін форм, способів та засобів збройної боротьби, самостійно набувати необхідних знань i застосовувати їх на практиці;

критично мислити, вміти побачити проблеми, що виникають у службовій діяльності, та шукати шляхи вирішення їх розв'язання, використовуючи сучасні технології;

грамотно працювати з інформацією;

бути комунікабельним, контактним у різноманітних соціальних групах, уміти працювати у колективі;

самостійно працювати над розвитком власного інтелекту, професійних знань та навичок.

Однак, на жаль, практика свідчить про те, що наявна на сьогодні система військової освіти неспроможна вчасно реагувати на зміни предметної галузі, що відбуваються. Тому, зовсім не випадково, одним із вирішальних факторів успішної трансформації та модернізації Збройних Сил України на сучасному етапі їх розвитку визнано саме широкомасштабну реформу цієї системи, наближення іï до реальних потреб військ.

Одним із напрямів реформи має стати створення дієвої системи безперервного навчання військових фахівців. Досвід бойових дій на Сході 
нашої країни свідчить про те, що дієвим інструментом вирішення зазначеного завдання може стати дистанційне навчання [7].

Як ми бачимо, у житті нашого суспільства відбуваються великі зміни в різних його сферах i, оскільки освіта носить випереджальний характер розвитку по відношенню до соціально-економічному розвитку суспільства, назріла необхідність законодавчого визначення i закріплення стратегії держави в розвитку системи освіти. Таким документом стала Стратегія національної безпеки України яка була затверджена Указом Президента України у 2015 році [1], де йдеться, у тому числі, й про “запровадження інтегрованої системи освіти, бойової і спеціальної підготовки персоналу для органів сектору безпеки і оборони із залученням викладачів, інструкторів із держав - членів НАТО, СС, формування нової культури безпеки". На основі Стратегії національної безпеки України був введений План дій щодо впровадження оборонної реформи у 2016-2020 роках (Дорожня карта оборонної реформи), де поставлено завдання удосконалення системи військової освіти та підготовки кадрів та впровадження дистанційного навчання у ВВНЗ.

Одним із шляхів, що забезпечують випереджальний розвиток освіти, $\epsilon$ використання інформаційних технологій і розвиток системи дистанційного навчання. В першу чергу, активізації цього процесу сприяє розвиток глобальної мережі Internet, web-технологій та інших засобів комунікації, які надали нові можливості у розвитку цієї форми навчання.

Також це обумовлено реаліями сучасного життя: все більшої кількості фахівців необхідно в жорстких умовах обмеженого часу отримати спеціалізовану військову освіту, i, по-друге, поповнення певного багажу додаткових знань. У системі військової освіти, що є частиною системи професійного освіти в цілому, зросли вимоги рівня підготовки офіцерів, особливо під час проведення антитерористичної операції.

Тому однією з суттєвих завдань системи військової освіти, є формування спеціального середовища i умов, що забезпечать і дозволять максимально використовувати всі потенційні можливості військової освіти 3 використанням дистанційних технологій навчання. Відповідно до концепції реформи військової освіти ведеться активна робота 3 пошуку нових, більш ефективних інформаційних технологій освіти, які дозволили б вивести підготовку військових фахівців на якісно новий рівень, де розглядається можливість впровадження дистанційного навчання у військових ВНЗ на базі комп'ютерних технологій і супутникових телекомунікацій .

Дистанційну форму навчання фахівці зі стратегічних проблем освіти називають освітньою системою 21 століття. Сьогодні на неї зроблена величезна ставка. Актуальність теми дистанційного навчання полягає в тому, що результати суспільного прогресу, які раніше були зосереджені в сфері технологій сьогодні концентруються в інформаційній сфері. Настала ера інформатики. Етап iㅣ розвитку в даний момент можна охарактеризувати як телекомунікаційний, це область спілкування, інформації і знань. 
Дистанційне навчання - це варіант реалізації заочної форми навчання, який грунтується на використанні сукупності сучасних технологій, що забезпечують доставку інформації за допомогою використання інформаційно-комунікаційних технологій.

Основними принципами дистанційного навчання $€$ інтерактивна взаємодія у процесі навчання, надання слухачам можливості самостійної роботи $з$ освоєння навчального матеріалу, а також консультаційний супровід у процесі навчальної діяльності. Така технологія дає змогу навчатися на відстані.

Створення у ВВНЗ системи єдиного освітнього простору на основі використання дистанційного навчання сприятиме розвитку інформаційноосвітньої мережі для підготовки фахівців Збройних Сил України. Вона стає центром безперервної освіти на основі мережевих технологій і суттєво дозволить вирішити ряд проблем підготовки, перепідготовки та підвищення кваліфікації військових фахівців дистанційними методами.

Звичайно, сьогодні в деяких ВВНЗ України впроваджені дистанційні методи навчання в процес підготовки офіцерів, але в більшості випадків вони мають експериментальний характер i не дивлячись на актуальність дистанційного навчання в процесі підготовки офіцерів, вони ще не отримали належного розвитку у військових ВНЗ.

Впровадження системи дистанційного навчання у систему підготовки офіцерів дозволить на практиці реалізувати систему безперервної освіти та розширити контингент учнів за рахунок сержантського і рядового складів.

Виходячи 3 того, що професійні знання старіють дуже швидко, то їх необхідно постійно вдосконалювати, дистанційна форма навчання дає сьогодні можливість створення систем масового безперервного навчання, загального обміну інформацією, незалежно від часових і просторових поясів.

Висновки. Створення в військових навчальних закладах системи єдиного освітнього простору на основі дистанційного навчання, сприятиме розвитку інформаційно-освітньої мережі для підготовки військових фахівців для Збройних Сил України. Воно стане центром безперервної освіти на основі мережевих технологій i суттєво активізує процес підготовки військових фахівців, при цьому використання інформаційно-освітньої мережі буде потужним засобом підвищення рівня знань і основою безперервної освіти.

Саме ця система, на мою думку, може найбільш адекватно і гнучко реагувати на потреби Збройних Сил України у підготовці військових фахівців в умовах сьогодення.

Тому, дистанційне навчання - це технологія майбутнього. Воно може застосовуватися в військовій освіті, здійснювати широке коло завдань освіти, навчання, виховання та розвитку особистості військовослужбовця. Тому необхідно розробляти та впроваджувати нові розробки для дистанційних форм навчання у Збройних Силах України. 
1. Кухаренко В.М., Рибалко О.В.,Сиротенко Н.Г. Дистанційне навчання: умови застосування. Дистанційний курс: Навч. Посібник 3-е вид. / За ред. Кухаренка В.М. Харків: НТУ “ХІІ”, “Тарсінг”, - 2002.

2. Бершадский А.М., Кревский И.Г. Дистанционное обучение - форма или метод. / А.М. Бершадский, И.Г. Кревский // Дистанционное образование, - 1998. - № 4.

3. Козлакова Г.О. Інформаційно-програмне забезпечення дистанційної освіти: зарубіжний і вітчизняний досвід: Монографія / АПН України. Ін-т вищ. Освіти. К., - 2002. $-231 \mathrm{c}$.

4. Дмитренко П.В., Пасічник Ю.А. Дистанційна освіта. - К.: НПУ, 1999.

5. Закон України "Про вищу освіту” від 01.07.2014 p. N 1556-VII Стаття 42.

6. Концепція розвитку дистанційної освіти в Україні. (затверджено Постановою МОН України від 20.12.2000 р.).

7. Радецкий В.Г. Впровадження технологій дистанційного навчання в системі військової освіти. Наука і оборона, - 2007 - № 3.

И.И. Кузьмич, кандидат юридических наук, полковник НУОУ имени Ивана Черняховского

УПРАВЛЕНИЕ ДИСТАНЦИОННЫМ ОБУЧЕНИЕМ В ВЫСШИХ ВОЕННЫХ УЧЕБНЫХ ЗАВЕДЕНИЯХ В СОВРЕМЕННЫХ УСЛОВИЯХ

В статье рассматривается актуальность и условия внедрения дистаничионного обучения в выстих военных учебных заведениях Украины как основной формы подготовки военных специалистов в сегодняшних условиях.

Ключевые слова: дистанционное обучение; Вооруженные Сильы Украины; система военного образования.

\section{I. Kuzmich, Ph.D, colonel NUDU named after Ivan Chernyakhovskij \\ MANAGEMENT OF REMOTE TRAINING IN HIGHER MILITARY EDUCATIONAL INSTITUTIONS IN MODERN CONDITIONS}

The article considers the relevance and conditions for introducing distance learning in higher military educational institutions of Ukraine as the main form of training military specialists in today's conditions.

Key words: distance education; Armed Forces of Ukraine; military education system. 